\title{
The Reflection of Applying New Developed Approaches in Accounting Information System on Investment and Credit Decisions in Commercial Banks in Aqaba Special Economic Zone
}

\author{
Mousa Mohammed Abdullah Saleh \\ Head of Department of Administrative and Financial Sciences \\ Al-Balqa Applied University, Aqaba University College \\ Dr. Ziad Odeh Ebniah Al Amaideh \\ Department of Accounting, Faculty of Business Administration \\ Mutah University \\ Dr. Haitham Mahmoud Abudalla Baniatta \\ Department of Finance \& Administrative Science, Ajlun University College \\ AL-Balqa Applied University \\ Dr. Ashraf Mohammad Salem Alrjoub \\ Department of Administrative and Financial Science, Irbid University College \\ AL-Balqa Applied University
}

Received: Nov. 8, 2013 Accepted: January 25, $2014 \quad$ Published: June 1, 2014

doi:10.5296/ajfa.v6i1.4527 URL: http://dx.doi.org/10.5296/ajfa.v6i1.4527

\begin{abstract}
This study aimed at investigating the applicability of applying commercial banks in Aqaba to the modern methods of accounting information systems in its accounting and usefulness of such data when making decisions related to the interests of the banks and their customers credit and investment interests and achieve client satisfaction, and if there are differences between those banks in the application of those regulations and the degree of utilization.
\end{abstract}


Study sample consisted of (10) commercial banks in the Aqaba Special economic zone, which have been selected based on the level of cooperation we got from the 17 banks.

The study found that the use of modern methods of accounting information systems in banks in the Aqaba Special economic zone have an impact on administrative decisions of the managers. The prepared budget based on modern accounting systems do not provide expected and accurate information to help the credit protection of the bank

Keywords: Commercial banks, Accounting information systems, Reflection, Investment, Credit Decisions, Aqaba Special Economic Zone 


\section{Introduction}

Banks have expanded in its work and functions to a new aspects due to the complexity of bank business in the world, and the change of the banks strategies in gaining customers and keeping them, it became important to it to have enough credit protection to keep the money of their clients and increase expected return from them to the customers, and to increase the proportion of revenues charged by banks.

Banks also play a vital role in the national economy through the dual role played by the compilation of national savings and accepting it in the form of deposits for generations on the one hand, and meanwhile employ the a large part of these deposits and savings in the form of credit facilities and loans to benefit all sectors of the national economy to fund its operations.

Add to that the many customers of those banks have resorted to it for advice and consulting on the assumption that these banks perform it work on a scientific basis, studies and deeper and wider experience than they have. And because those banks are designed to maintain and service their customers so they are required to provide all the data and information they require.

There for taking any credit or investment decision are a picture of the administrative and accounting system of the bank strength and durability and the accuracy of their expectations and data and the sensitiveness of its forecasts.

The accounting system applications have developed because of the of technology developed in the world, and Jordan is the fastest in using it. The use of these banks for this new technology will help them in providing data and information that suits the speed of changes in the world economic and financial markets, and will save time and effort for financial analyst as the modern accounting software provide information and rates that may help him in these banks to keep up with events and changes and taking the appropriate decisions at the appropriate time.

\section{The importance of the study}

The importance of the study came by linking modern methods in the modern accounting information systems with the environment of the commercial banks in Aqaba region taking into account that banking sector is an active sectors in Jordan's economy.

As the infrastructure of the information technology is one of the most important components of accounting information systems, so knowing the impact of methods on technological considerations must get some sort of attention, especially with regard to the impact of those methods on accounting information systems and thus the commercial banks in Aqaba city, having this in mind the study aims to:-

Stating the most important methods used in the use of accounting information systems

Stating the most important international standards issued by the international accounting conferences with regard to accounting information systems 
Studying the reality of accounting information systems used in terms of the extent of the application of the methods to modernize and develop of such systems and the degree of their influence on the decision-making process in the commercial banks in the Aqaba region

Show the impact of the methods used in the area of accounting information systems and its impact on credit and investment decision-making in business banks in the Aqaba region.

And with developments in accounting information systems in recent years, in the area of planning, control systems, management systems and quality properties of its output is expected to claim those methods to more efficiency and effectiveness in decision-making.

The key role played by the output of accounting information systems in decision-making requires an in-depth study on the impact of methods and techniques used in the design and development of accounting information systems to increase its effectiveness and the efficiency of the decision-making process in investment banks in the city of Aqaba but this impact goes over to pursue multiple aspects of work after decision-making, because the higher management can't take its decisions and draw its policy properly without specification of the quality and quantity of information provided to management with a degree of detail and analysis with precision and objectivity when delivering it taking into account providing these accounting information in appropriate time.

\section{The objective of the study}

The study aims to determine the extent of the application of commercial banks in Aqaba to modern methods of accounting information systems in its accounting and usefulness of such data when making decisions related to the interests of the banks and their customers in their credit and investment and achieve client satisfaction, and if there are differences between those banks in the application of those regulations and the degree of utilization.

The study also aims to measure the level of credit risk that the Bank will face if it decided to approve granting a client a certain amount of credit facilities, through information supplied by the modern accounting systems, giving credit is always accompanied by risk, and this is due to the banking fact is that: "no credit without risks" so we use this study to see what benefit that modern accounting system provide to reduce these risks, and try to reach a situation where we can be most sure .

And also aims to find the impact of application of modern accounting information systems and the evolution of its technologies, tools and it techniques and complexity and its impact on the efficiency and the performance of these systems which deal with banks on investment and credit transactions to improve and develop working procedures for the benefit of efficiency of these decisions.

\section{Problem of the study}

Taking any decision is considered as preferring one alternative from a range of alternatives based on thorough and sufficient analysis for the event, the problem or the situation. Financial resolution is one of the most important decisions taken by the banks for individuals, because its impact is reflected and quickly shown as either a profit or loss. 


\section{Macrothink

Banking institutions are based on full financial dealing therefore its strategies are based on protecting the deposited funds, increasing its revenues and maintaining the customers.

Financial decision making at the moment requires knowledge of the variables and the quickness of the procedure. And this can only be accessed through modern accounting systems that provide sufficient data and information, financial ratios and accurate financial analysis to help credit and investment decision taker to make that decision on the basis of being sure, accurate and in the required speed, to protect the Bank and the customer at the same time.

Therefore, we believe that modern accounting information systems will help in taking sound, valid, conform to the reality financial decisions (investment and credit) and with acceptable effect to the Bank and the customer.

\subsection{The following questions can be formulated through the problem of study}

1. Do commercial banks operating in the Aqaba region apply modern methods in accounting information systems?

2. Do banks benefit from the modern methods in accounting information systems in credit and investment decision-making in the banks operating in the Aqaba region?

3. Do managers and staff in banks benefit from the modern methods of accounting information systems in Aqaba in their decisions?

4. Do the clients of commercial banks operating in Aqaba benefit from information provided by modern accounting information systems in rationalizing their credit and investment decisions and in choosing their appropriate investment portfolio for them?

5. Is there a strong correlation between the output of modern accounting information systems and credit and investment decisions in banks operating in the Aqaba region?

\section{Methodology}

Descriptive and analytic methodology (experimental) has been used in this study to describe, interpret and analyze everything related to computerized accounting information systems.

\subsection{Study community}

Study community consists of all the (17) commercial banks in Aqaba.

\subsection{Study Sample}

Study sample consisted of 10 banks which were chosen based on the level of cooperation that we have received from banks.

\subsection{Hypotheses of the study}

A. Commercial banks operating in the Aqaba region apply modern methods in accounting information systems 
B. Banks benefit from the modern methods in accounting information systems in credit and investment decision-making in the banks operating in the Aqaba region

C. Managers and staff in banks benefit from the modern methods of accounting information systems in Aqaba in their decisions

D. The clients of commercial banks operating in Aqaba benefit from information provided by modern accounting information systems in rationalizing their credit and investment decisions and in choosing their appropriate investment portfolio for them.

E. There is a strong correlation between the output of modern accounting information systems and credit and investment decisions in banks operating in the Aqaba region

\subsection{Study Limitation}

A. Place limitation: researcher meant by this the commercial banks operating in the Aqaba Special economic zone.

B. Time limitation: the researcher applied field procedures for study tools on commercial banks operating in Aqaba during 2010/2011.

\section{Previous studies}

Al Mushrike study entitled" the role of information technology in analyzing problems and decision making in the industrial service organizations”. The study used the descriptive analytical approach that depends on the theoretical studies which have interest in studying the way that these industrial service organizations are managed by through using the appropriate technology for each one to reach the stage of making organizational decisions in them to reach higher or lower payments.

The information systems based on the computer may support the organizational decision through facilitating the communication process between the participants in the decision making.

The study recommended the amendment of the technology to suite the strategies of the service organizations, and the necessity to make harmony between the routine decision for the department and the non routine ones.

The first type requires routine information (frequent and detailed) the second type requires information that is non-routine which means that the taken decision require skills and time), they are substantive decisions affect the whole organization

1. Khaled (2004) study, entitled: "evaluate the performance of the accounting systems of computer-based appropriateness to meet management needs". this study aimed to evaluate the performance of the computer-based accounting systems in the services and trade sector from various dimensions, (technical, behavioral and human) through the identification of the extent of efficiency and effectiveness as in the performance of its tasks, from human side to identify the satisfaction expressed by users of these systems and outputs. 
this study aimed to analyze some factors effecting the performance of these systems, the results of the study have shown that systems have a significant degree of effectiveness in achieving its objectives it showed that it is recognized with their ease of use and handle, speed and accuracy in it input and manipulating data with flexibility and integration with internal functions with other systems so you can enter adjustments to suit the environment and user needs.

This makes it able to perform the required functions and to maintain a level of performance in different circumstances, and is recognized by a quality set of rules and control procedures that supports accuracy and increases the possibility of depending on it.

The study recommends giving priority to environmental systems benefit from the modern technological methods such as networks and the Internet, the user participation in systems development and design.

It also recommends accounting students to develop their capacities and skills in the area of computer and learning how programming and design of such systems, the study also recommends assessing the performance of accounting systems based on computer in the service and commercial sectors.

2. Sharif study (2006): "risk of electronic accounting information systems "

This study aims to identify the risks of electronic accounting information systems in bank, identified the main causes that lead to such risks and actions to prevent those risks.

The following conclusions have been reached:

- $\quad$ Good management can reduce or limit the occurrence of risks facing the bank accounting information systems.

- Application of information systems security procedures reduces the potential risk of accounting information systems.

3. Almhasnh study (2005): "the impact of the efficiency of information systems in the effectiveness of the decision-making process".

The study aims to identify the impact of the efficiency of information systems in the effectiveness of the process of making decisions, the study recognize the role of managers in the organizations in providing a basic rule of inclusiveness and specialized information systems to strengthen their role in sound decision-making. The most important results of the study indicate the impact of information systems to support physical, financial, technical, human and administrative in defining the problem and developing and comparing alternatives in control and follow-up.

The study recommended that senior management should provide support to users through encouraging them to use the system, identify their needs, participate in the development of computerized information system, strengthening the relationship between users of information systems and the responsible people of this system then later set up training programs for users and increased attention to the human and material inputs and finance. 
4. Seam (2004): "assessment of the effectiveness of computerized accounting information systems in Jordanian commercial banks under technological development."

This study aimed to evaluate the effectiveness of information systems and accounting systems in Jordanian commercial banks under technological development through a set of agenda that reflects the effectiveness of the performance of such systems of quality and flexibility, simplicity and reliability.

The study concentrates on the role of accounting information systems as a backbone between information systems in banks, by what these systems of accounting information summarizing the events and processes that have been used in the Bank, and the resulting information necessary for effective decision-making. The results of the study showed that the computerized accounting information systems in commercial banks of Jordan are characterized by the availability of four characteristics (quality, flexibility, simplicity, reliability).

5. Abdel Raziq (1993), entitled: "the use of computer information in administrative decisions relating to planning and control functions", applied study in Jordanian general corporate companies ". This study was to determine the extent of the use of accounting information in administrative decisions relating to planning, controling functions and application to all (41) Jordanian industrial corporations listed in Amman financial market. One of the most important findings of the study that most Jordanian industrial companies use accounting information, and convergent rates when making administrative decisions concerning the planning function or control or both of them.

6. Kokhon (1988), the accounting control under electronic systems and their applications in the Jordanian Central Bank.

This study aimed to follow the procedures established in the Department of computer control in the Central Bank of Jordan, in its electronic accounting, compared to the control procedures that should be followed to enable checking control procedures and follow the latest scientific methods in the application of these procedures, the researcher used in her study the descriptive and analytical study of accounting control procedures in the electronic financial systems:.

The study focused on the accounting control procedures, both the general control and the control on the application in computer service, and electronic accounting system, the study of electronic accounting system in the Jordanian Central Bank and regulatory procedures followed in both phases of the system input stage or stage of data processing or output stage.

\subsection{The most important characteristic of our previous studies}

The most important feature of our previous studies that it taken into account all affecting participant on accounting systems and its modern methods: bank managers/staff of the banks/investors/customers. 
The study results was also characterized by the ability to circulate its results to all banks (commercial and investment) because all the banks uses trade as a major activity of its dealings, given its high profitability.

Through the review of previous studies, it has been utilized in the theoretical side of the study as follows:-

1. Studying accounting information systems impact on the decision-making process of the Bank.

2. Factors affecting accounting information systems (environmental, organization ...).

3. The extent to which management depend on information systems in connection with decision making.

\subsection{Data analysis and hypothesis testing}

Tool consistency:

* The consistency of the tool has been tested by using Cronbach's alpha, looking at table 1 we can notice the following:

1. alpha value for the application of modern methods in accounting information systems dimension was 0.84

2. alpha value for benefit from modern methods in decision-making dimension was 0.64

3. alpha value for the effect of using modern methods on administrative decisions dimension was 0.69

4. alpha value for customers benefit form information in rationalizing their decisions dimension was 0.85

5. alpha value for relationship between systems output with credit decisions and investment dimension was 0.6

6. Alpha value to all paragraphs combined was 0.91

\section{All these values are greater than 0.60 which means that the study tool is consistence.}




\section{Macrothink}

Table 1. results of Cronbach's alpha:

\begin{tabular}{|l|c|}
\hline Dimension & Alpha value \\
\hline $\begin{array}{l}\text { Application of modern methods in accounting information } \\
\text { systems }\end{array}$ & 0.843 \\
\hline Benefit from modern methods in decision-making & 0.640 \\
\hline The effect of using modern methods on administrative decisions & 0.697 \\
\hline $\begin{array}{l}\text { Customers benefit from information in rationalizing their } \\
\text { decisions }\end{array}$ & 0.065 \\
\hline $\begin{array}{l}\text { Relationship of output systems with investment and credit } \\
\text { decisions }\end{array}$ & 0.686 \\
\hline Total & 0.911 \\
\hline
\end{tabular}

Tool reliability:

The reliability of the tool has been checked through:

1. Displaying it to a number of arbitrators to make sure that all paragraphs reflect the areas to which they belong. In the light of the observations some paragraphs were amended to become clearer in terms of language and belonging to the dimension.

2. Honesty of the tool has been confirmed also by using factor analysis tool to check how phrases are related to the dimension to which they belong to.

\section{Description of demographics and profile of respondents:}

First: sex:

Table 7 shows that $63.5 \%$ of the sample was male and the rest are female.

Table 7. Frequency and the percentage of gender variable

\begin{tabular}{|l|l|l|}
\hline gender & Frequency & percentage\% \\
\hline Male & 54 & 63.5 \\
\hline Females & 31 & 36.5 \\
\hline
\end{tabular}

Second: age

Table 8 shows that $42.4 \%$ of the sample were between $25-34$ years, $30.6 \%$ of the respondents aged less than 25, $21.2 \%$ aged $35-44$ years old, and $5.9 \%$ equal to or over the age of 45 .

Table 8. Frequency and the percentage of age variable

\begin{tabular}{|l|l|c|}
\hline Age & Frequency & percentage\% \\
\hline Less than 25 & 26 & 30.6 \\
\hline
\end{tabular}




\begin{tabular}{|l|l|l|}
\hline $25-34$ & 36 & 42.4 \\
\hline $35-44$ & 18 & 21.2 \\
\hline = or Greater than 45 & 5 & 5.9 \\
\hline
\end{tabular}

Third: qualification

Table (9) shows that $77.6 \%$ of the study sample are BS holders, 15.3\% diploma, 4.7 master's degrees and $2.4 \%$ are secondary or less.

Table 9. Frequency and the percentage of qualification variable

\begin{tabular}{|l|l|c|}
\hline qualification & Frequency & percentage\% \\
\hline $\begin{array}{l}\text { Secondary and } \\
\text { below }\end{array}$ & 2 & 2.4 \\
\hline average Diploma & 13 & 15.3 \\
\hline BS & 66 & 77.6 \\
\hline Master & 4 & 4.7 \\
\hline MD & - & - \\
\hline
\end{tabular}

Fourth: specialization

Table 10 shows that $40.0 \%$ of sample is accounting specialization, $18.8 \%$ of respondents are business management specialization, and 16.5 percent are financial Sciences specialization, $7.1 \%$, of them are economic and $17.6 \%$ from other disciplines.

Table 10. frequencies and the percentage of specialization variable

\begin{tabular}{|l|l|l|}
\hline specialization & Frequency & percentage\% \\
\hline Accounting & 34 & 40.0 \\
\hline Business & 16 & 18.8 \\
\hline Economy & 6 & 7.1 \\
\hline financial science & 14 & 16.5 \\
\hline other & 15 & 17.6 \\
\hline
\end{tabular}

Fifth: years of experience:

Table 11 shows that $43.5 \%$ of sample experiences is from one to 5 years and $24.7 \%$ of them their experience is over than or equal to 10 years. And $21.2 \%$ of them their experience is between 5-or less than 10 years. And 10.6\% are less than one year of experience. 
Table 11. frequencies and the percentage of experience variable

\begin{tabular}{|l|l|l|}
\hline experience & Frequency & percentage\% \\
\hline Less than a year & 9 & 10.6 \\
\hline 1. less than 5 & 37 & 4305 \\
\hline 5. less than 10 & 18 & 21.2 \\
\hline $\begin{array}{l}\text {, Greater than } \\
10\end{array}$ & 21 & 24.7 \\
\hline
\end{tabular}

Hypothesis testing and results of the analysis

Hypothesis 1:

Commercial banks operating in the Aqaba Special economic zone apply modern methods in accounting information systems.

Table 12 shows the following:

With the exception of paragraphs 7, 8, all other paragraphs got arithmetical mean bigger than 3.00 and observation level less than 0.05 , i.e. it is statistically significant, meaning that all these things are available. Paragraph no. 4 which measures the extent of using modern methods of accounting information systems came in the first place with 4.31 arithmetical mean. Paragraph no. 1 which measures the extent of using modern methods for accounting information systems planning in second place with 4.29 arithmetical mean. Paragraph No. 9, which measure the effectiveness of electronic devices available in banks last place within statistically acceptable paragraphs with 4.01 arithmetical mean.

Paragraph no. 7 though arithmetical mean was greater than 3.00 but the observation level was greater than 0.05 , i.e. it does not use modern methods to develop accounting information systems.

Paragraph No. 8 got 3.19 arithmetical mean which is greater than 3.00, the observation level was greater than 0.05 i.e. is not statistically significant, i.e. it does not use modern methods to develop the skills of interaction between users of accounting information systems and those systems.

All paragraphs have got 3.96 arithmetical mean, the observation level is 0.00 which is less than 0.05. I.e. the first hypothesis is accepted, which means that any commercial banks operating in the Aqaba Special economic zone apply modern methods in accounting information systems. 


\section{Ml Macrothink}

Asian Journal of Finance \& Accounting ISSN 1946-052X 2014, Vol. 6, No. 1

Table 12. Arithmetic mean, standard deviation and the value of $\mathrm{t}$ and observation level related to the application of modern methods in accounting information systems

\begin{tabular}{|c|c|c|c|c|c|}
\hline No. & paragraph & $\begin{array}{l}\text { Arithmetic } \\
\text { mean }\end{array}$ & $\begin{array}{l}\text { standard } \\
\text { deviation }\end{array}$ & $\begin{array}{l}\mathrm{t} \\
\text { value }\end{array}$ & $\begin{array}{l}\text { observation } \\
\text { level }\end{array}$ \\
\hline 1. & $\begin{array}{l}\text { organization uses modern methods } \\
\text { of accounting information systems } \\
\text { planning }\end{array}$ & 4.29 & 0.67 & 17.82 & 0.00 \\
\hline 2. & $\begin{array}{l}\text { organization uses modern methods } \\
\text { of accounting information systems } \\
\text { security }\end{array}$ & 4.28 & 0.76 & 16.00 & 0.00 \\
\hline 3. & $\begin{array}{l}\text { organization employs modern } \\
\text { methods of accounting information } \\
\text { systems }\end{array}$ & 4.22 & 0.76 & 14.81 & 0.00 \\
\hline 4. & $\begin{array}{l}\text { organization uses modern methods } \\
\text { of accounting information systems } \\
\text { application }\end{array}$ & 4.31 & 0.74 & 16.26 & 0.00 \\
\hline 5. & $\begin{array}{l}\text { organization uses modern methods } \\
\text { to support accounting information } \\
\text { systems }\end{array}$ & 4.13 & 0.80 & 13.04 & 0.00 \\
\hline 6. & $\begin{array}{l}\text { organization employs modern } \\
\text { methods to monitor the performance } \\
\text { of accounting information systems }\end{array}$ & 4.14 & 0.77 & 13.60 & 0.00 \\
\hline 7. & $\begin{array}{l}\text { organization uses modern methods } \\
\text { to develop accounting information } \\
\text { systems applied in it }\end{array}$ & 3.09 & 1.02 & 0.85 & 0.40 \\
\hline 8. & $\begin{array}{l}\text { organization employs modern } \\
\text { methods to develop the skills of } \\
\text { interaction between users of } \\
\text { accounting information systems and } \\
\text { those systems }\end{array}$ & 3.19 & 1.10 & 1.58 & 0.12 \\
\hline 9. & $\begin{array}{l}\text { electronic devices available to the } \\
\text { Bank are of a high efficiency }\end{array}$ & 4.01 & 1.01 & 9.27 & 0.00 \\
\hline & Total & 3.96 & 0.47 & 18.88 & 0.00 \\
\hline
\end{tabular}

Hypothesis 2:

Banks benefits from modern accounting information systems in credit and investment decision-making in commercial banks operating in the Aqaba Special economic zone.

Table 13 shows the following:

With the exception of paragraphs, 12 all other paragraphs got arithmetical mean bigger than 3.00 and observation level less than 0.05, i.e. it is statistically significant. Paragraph no. 10 which measures the extent to which modern accounting systems help in determining the 
amount of the loan that may be granted for investment came in the first place with 4.27 arithmetical mean. Paragraph no. 15 which measures the extent to which modern accounting systems help in determining the amount of time required to repay the loan in second place with 4.25 arithmetical mean. Paragraph No. 13, which measure the impact of modern methods of accounting information systems to make a decision last place within statistically acceptable paragraphs with 4.14 arithmetical mean.

Paragraph no. 12 arithmetical mean was greater than 3.00 but the observation level was greater than 0.05 , i.e. the banks don't make any studies on investment stages to be distributed to shareholders.

All paragraphs have got 4.05 arithmetical mean, the observation level is 0.00 which is less than 0.05 . I.e. the second hypothesis is accepted, that banks benefit from modern accounting information systems in credit and investment decision-making in commercial banks operating in the Aqaba Special economic zone

Table 13. arithmetic mean, standard deviation, the value of $t$ and the level of significance of taking advantage of modern method in decision-making

\begin{tabular}{|c|c|c|c|c|c|}
\hline No. & paragraph & $\begin{array}{l}\text { Arithmetic } \\
\text { mean }\end{array}$ & $\begin{array}{l}\text { standard } \\
\text { deviation }\end{array}$ & t value & $\begin{array}{l}\text { observation } \\
\text { level }\end{array}$ \\
\hline 10. & $\begin{array}{l}\text { modern accounting systems are } \\
\text { used in determining the amount } \\
\text { of the loan that could be granted } \\
\text { for client investment. }\end{array}$ & 4.27 & 0.73 & 16.05 & 0.00 \\
\hline 11. & $\begin{array}{l}\text { application of modern methods in } \\
\text { accounting information systems } \\
\text { is important for Bank action }\end{array}$ & 4.22 & 0.90 & 12.47 & 0.00 \\
\hline 12. & $\begin{array}{l}\text { Bank conduct studies on } \\
\text { investment stages and distributes } \\
\text { it to shareholders. }\end{array}$ & 3.05 & 0.83 & 0.52 & 0.60 \\
\hline 13. & $\begin{array}{l}\text { modern methods of accounting } \\
\text { affect information systems for } \\
\text { decision-making. }\end{array}$ & 4.14 & 0.73 & 14.49 & 0.00 \\
\hline 14. & $\begin{array}{l}\text { accounting information system is } \\
\text { features with the speed of the } \\
\text { connection between itself and its } \\
\text { users. }\end{array}$ & 4.21 & 0.73 & 15.40 & 0.00 \\
\hline 15. & $\begin{array}{l}\text { modern accounting systems } \\
\text { help in determining the time } \\
\text { required to repay the loan. }\end{array}$ & 4.25 & 0.65 & 17.61 & 0.00 \\
\hline 16. & $\begin{array}{l}\text { modern accounting systems help } \\
\text { in accelerating the } \\
\text { decision-making process in credit }\end{array}$ & 4.21 & 0.76 & 14.75 & 0.00 \\
\hline
\end{tabular}




\begin{tabular}{|l|l|l|l|l|r|}
\hline & $\begin{array}{l}\text { and investment commercial } \\
\text { banks. }\end{array}$ & & & & \\
\hline & Total & 4.05 & 0.38 & 25.29 & 0.00 \\
\hline
\end{tabular}

The third hypothesis:

The use of modern methods of accounting information systems in banks in the Aqaba Special economic zone has an impact on administrative decisions made by managers.

Table 14 shows the following:

With the exception of paragraphs 23 all other paragraphs got arithmetical mean bigger than 3.00 and observation level less than 0.05 , i.e. it is statistically significant. Paragraph no. 21 which measures the extracted estimated financial statements under modern methods to reduce credit risk, came in the first place with 4.26 arithmetical mean. Paragraph no. 22 which measures the extent to which modern accounting information systems identifying the functions of staff to facilitate their work in second place with 4.21 arithmetical mean. Paragraph No. 19, which measure the support of information of accounting information systems managers to better distribution of investment resources for the Bank last place within statistically acceptable paragraphs with 4.00 arithmetical mean.

Paragraph no. 23 arithmetical mean was greater than 3.00 but the observation level was greater than 0.05 , i.e. that there is difficulty in the use of accounting information systems or part of it.

All paragraphs have got 4.00 arithmetical mean, the observation level is 0.00 which is less than 0.05. I.e. the second hypothesis is accepted, the use of modern methods of accounting information systems in banks in the Aqaba Special economic zone has an impact on administrative decisions made by managers.

Table 14. arithmetic mean, standard deviation and the value of $t$ and observation level related to effect of suing modern method in making administrative decisions

\begin{tabular}{|l|l|l|l|l|l|}
\hline $\begin{array}{l}\mathrm{N} \\
\text { o. }\end{array}$ & Paragraph & $\begin{array}{l}\text { Arithmetic } \\
\text { mean }\end{array}$ & $\begin{array}{l}\text { standard } \\
\text { deviation }\end{array}$ & t value & $\begin{array}{l}\text { observati } \\
\text { on level }\end{array}$ \\
\hline $\begin{array}{l}17 \\
.\end{array}$ & $\begin{array}{l}\text { Accounting information systems } \\
\text { provide mangers need to finish jobs } \\
\text { and make their decisions in the } \\
\text { expected way. }\end{array}$ & 0.19 & 12.09 & 0.00 \\
\hline 18 & $\begin{array}{l}\text { Modern accounting information } \\
\text { systems benefits in helping the } \\
\text { mangers to determine the available } \\
\text { amount of money for investment. }\end{array}$ & 0.05 & 13.68 & 0.00 \\
\hline 19 & $\begin{array}{l}\text { Modern accounting information } \\
\text { systems benefit managers in the best }\end{array}$ & 4.00 & 0.80 & 11.50 & 0.00 \\
\hline
\end{tabular}




\begin{tabular}{|c|c|c|c|c|c|}
\hline & $\begin{array}{l}\text { distribution for the special investments } \\
\text { in the bank }\end{array}$ & & & & \\
\hline 20 & $\begin{array}{l}\text { Modern accounting information } \\
\text { systems offer information on balance } \\
\text { of loan at any time to help managers to } \\
\text { take the appropriate decision. }\end{array}$ & 4.19 & 0.68 & 16.08 & 0.00 \\
\hline 21 & $\begin{array}{l}\text { estimated financial statements } \\
\text { extracted under modern methods helps } \\
\text { in reducing credit risk. }\end{array}$ & 4.26 & 0.76 & 15.30 & 0.00 \\
\hline 22 & $\begin{array}{l}\text { modern accounting information } \\
\text { systems is working on identifying the } \\
\text { functions of staff to facilitate their } \\
\text { work. }\end{array}$ & 4.21 & 0.80 & 13.91 & 0.00 \\
\hline 23 & $\begin{array}{l}\text { there is no difficulty in using } \\
\text { accounting information systems or part } \\
\text { of it. }\end{array}$ & 3.12 & 0.93 & 1.17 & 0.25 \\
\hline & Total & 4.00 & 0.44 & 20.78 & 0.00 \\
\hline
\end{tabular}

Hypothesis 4:

Clients of commercial banks benefit from information provided by modern accounting information systems in credit and investment decisions on rationalization and choosing the appropriate investment portfolio.

Table 15 shows the following:

All paragraphs got arithmetical mean bigger than 3.00 and observation level less than 0.05 , i.e. it is statistically significant. Paragraph no. 28 which measures the extent of usefulness of specific evaluated accounting systems in modern accounting systems in reducing the risks of credit offered to clients came in the first place with 4.19 arithmetical mean. Paragraph no. 29 which measures the extent to which modern accounting information systems helps in providing the customer with a return on each investment tool available in the Bank in second place with 4.12 arithmetical mean. Paragraph No. 19, which measure the supporting of accounting information systems for customer diversification of investment instruments in their investment portfolio last place with 4.01 arithmetical mean.

All paragraphs combined have got 4.08 arithmetical mean, the observation level is 0.00 which is less than 0.05. I.e. the fourth hypothesis is accepted, clients of commercial banks benefit from information provided by modern accounting information systems in credit and investment decisions on rationalization and choosing the appropriate investment portfolio. 


\section{Ml Macrothink}

Asian Journal of Finance \& Accounting ISSN 1946-052X 2014, Vol. 6, No. 1

Table 15. Arithmetic mean, standard deviation and the value of $\mathrm{t}$ and observation level related to customers benefiting form information in rationalizing their decisions

\begin{tabular}{|c|c|c|c|c|c|}
\hline No. & Paragraph & $\begin{array}{l}\text { Arithmetic } \\
\text { mean }\end{array}$ & $\begin{array}{l}\text { standard } \\
\text { deviation }\end{array}$ & t value & $\begin{array}{l}\text { observation } \\
\text { level }\end{array}$ \\
\hline 24 & $\begin{array}{l}\text { accounting information systems } \\
\text { help clients for better to diversify } \\
\text { their portfolios investment tools. }\end{array}$ & 4.01 & 0.84 & 11.13 & 0.00 \\
\hline 25 & $\begin{array}{l}\text { modern accounting information } \\
\text { systems benefit in assisting the } \\
\text { client to choose the appropriate } \\
\text { investment portfolio for his } \\
\text { orientation. } 0.00\end{array}$ & 4.06 & 0.70 & 14.02 & 0.00 \\
\hline 26 & $\begin{array}{l}\text { modern accounting systems } \\
\text { helps to determine the } \\
\text { appropriate time to make various } \\
\text { credit services to customers. }\end{array}$ & 4.08 & 0.85 & 11.77 & 0.00 \\
\hline 27 & $\begin{array}{l}\text { accounting systems provide } \\
\text { information on the Bank's credit } \\
\text { ceilings for each client. }\end{array}$ & 4.00 & 0.67 & 13.71 & 0.00 \\
\hline 28 & $\begin{array}{l}\text { estimated accounting systems } \\
\text { specified according to the in } \\
\text { modern accounting systems to } \\
\text { reduce credit risks for customers. }\end{array}$ & 4.19 & 0.68 & 16.08 & 0.00 \\
\hline 29 & $\begin{array}{l}\text { modern accounting information } \\
\text { systems provides the customer } \\
\text { with a return on investment of } \\
\text { each tool available in the Bank }\end{array}$ & 4.12 & 0.73 & 14.11 & 0.00 \\
\hline 30 & $\begin{array}{l}\text { modern accounting information } \\
\text { systems offers information on } \\
\text { each customer balance quickly. }\end{array}$ & 4.09 & 0.87 & 11.63 & 0.00 \\
\hline & Total & 4.08 & 0.41 & 24.24 & 0.00 \\
\hline
\end{tabular}

Hypothesis 5:

There is a strong relationship between output of modern accounting information systems and credit and investment decisions in the commercial banks in the Aqaba Special economic zone.

Table 16 shows:

With the exception of paragraphs, 35 all other paragraphs got arithmetical mean bigger than 3.00 and observation level less than 0.05 , i.e. it is statistically significant. Paragraph no. 34 
which measures the use of the published accounting reports in providing data about the client in terms of top roof for credit that can be granted to the customer, came in the first place with 4.14 arithmetical mean. Paragraph no. 37, which measures the availability of modern accounting systems that accept the credit risk of the Bank in second place with 4.07 arithmetical mean. Paragraph No. 33, which measure the help provided to the client from the information of the modern information accounting systems in making his investment portfolio through its systems in the published financial statements last place within statistically acceptable paragraphs with 3.98 arithmetical mean.

Paragraph no. 35 arithmetical mean was greater than 3.00 but the observation level was greater than 0.05 , i.e. the prepared budget on the basis of modern accounting systems do not provide accurate information to helps the Bank in credit protection.

paragraph 38 got arithmetical mean greater than 3.00, and the observation level greater than 0.05 , so it's not statistically significant, meaning that modern accounting systems are not useful in identifying areas where the Bank could invest in.

All paragraphs have 3.83 arithmetical mean, the observation level is 0.00 , which is less than 0.05. I.e. the fifth hypothesis is accepted, there is a strong relationship between output of modern accounting information systems and credit and investment decisions in the commercial banks in the Aqaba Special economic zone.

Table 16. Arithmetic mean, standard deviation and the value of $t$ and observation level related to the relation between the systems output and the investment and credit decision

\begin{tabular}{|c|c|c|c|c|c|}
\hline No. & Paragraph & $\begin{array}{l}\text { Arithmetic } \\
\text { mean }\end{array}$ & $\begin{array}{l}\text { standard } \\
\text { deviation }\end{array}$ & t value & $\begin{array}{l}\text { observation } \\
\text { level }\end{array}$ \\
\hline 31 & $\begin{array}{l}\text { Bank employees benefit from } \\
\text { published financial statements in } \\
\text { weighting investment decisions. }\end{array}$ & 4.05 & 0.84 & 11.44 & 0.00 \\
\hline 32 & $\begin{array}{l}\text { Bank employees benefit from } \\
\text { published financial statements in } \\
\text { the weighting of credit decisions. }\end{array}$ & 4.02 & 0.77 & 12.24 & 0.00 \\
\hline 33. & $\begin{array}{l}\text { information of modern } \\
\text { accounting information systems } \\
\text { helps client in configuration of } \\
\text { his portfolio through the what } \\
\text { is provided in the system of the } \\
\text { published financial statements }\end{array}$ & 3.98 & 0.65 & 13.76 & 0.00 \\
\hline 34 & $\begin{array}{l}\text { published accounting reports are } \\
\text { used in providing data on the }\end{array}$ & 4.14 & 0.62 & 16.97 & 0.00 \\
\hline
\end{tabular}




\begin{tabular}{|c|c|c|c|c|c|}
\hline & $\begin{array}{l}\text { client in terms of top roof for } \\
\text { credit that can be granted to the } \\
\text { client. }\end{array}$ & & & & \\
\hline 35 & $\begin{array}{l}\text { prepared budget on the basis of } \\
\text { modern accounting systems } \\
\text { provides unexpectedly accurate } \\
\text { information that helps the Bank } \\
\text { to credit protection }\end{array}$ & 3.14 & 1.14 & 1.15 & 0.26 \\
\hline 36 & $\begin{array}{l}\text { modern accounting systems } \\
\text { provide good credit protection for } \\
\text { banks through the identification } \\
\text { of appropriate ceiling for credit. }\end{array}$ & 4.04 & 0.70 & 13.68 & 0.00 \\
\hline 37 & $\begin{array}{l}\text { modern accounting systems } \\
\text { provide the extent of credit risk } \\
\text { that bank accepts }\end{array}$ & 4.07 & 0.75 & 13.12 & 0.00 \\
\hline 38 & $\begin{array}{l}\text { modern accounting systems } \\
\text { helps in determining the areas in } \\
\text { which the Bank invest in }\end{array}$ & 3.20 & 1.01 & 1.83 & 0.07 \\
\hline & Total & 3.83 & 0.41 & 18.63 & 0.00 \\
\hline
\end{tabular}

\section{Results}

The study found the following results:

1. Commercial banks operating in the Aqaba Special economic zone apply modern methods in accounting information systems.

2. Modern methods are not used to develop accounting information systems applied in them.

3. Modern methods are not used to develop the skills of interaction between users of accounting information systems and those systems

4. Banks benefit from modern accounting information systems in credit and investment decision-making in commercial banks operating in the Aqaba Special economic zone.

5. Banks don't prepare studies on investment stages to be distributed to shareholders.

6. The use of modern methods of accounting information systems in banks in the Aqaba Special economic zone has an impact on administrative decisions for the managers.

7. There is a difficulty in the use of accounting information systems or part of it.

8. Clients of commercial banks benefit from information provided by modern accounting information systems in rationalizing their credit and investment decisions and choosing the appropriate investment portfolio. 


\section{Macrothink}

Asian Journal of Finance \& Accounting ISSN 1946-052X 2014, Vol. 6, No. 1

9. There is a strong relationship between output of modern accounting information systems and credit and investment decisions in the commercial banks in the Aqaba Special economic zone.

10. Finical budget prepared on the basis of modern accounting systems do not provide accurate and expected information to help the Bank in credit protection

11. Modern accounting systems are useful in identifying areas where the Bank could invest in them.

\section{Recommendations}

The study recommends the following:

1. Banks in Aqaba should use modern methods to develop accounting information systems applied to it.

2. The study recommends using modern methods to develop interaction skills between users of accounting information systems and those systems.

3. The need to prepare studies on investment stages to be distributed to shareholders.

4. Trying to overcome the difficulty of using accounting information systems or any part of it.

5. working on the development of finical budget prepared on the basis of modern accounting systems that provide accurate and expected information to help the Bank credit protection

6. Activation of modern accounting systems to be able to identify areas where bank could invest in.

7. The study recommends the need for continuous improvement in accounting information systems for its positive role in credit and investment decision-making.

8. Making further studies on the role of modern methods in accounting information systems in decision making other than credit and investment decisions.

\section{References}

Abed Al Razak Mohammed Qasim. (2003). computerized accounting information systems, international scientific centre for publishing and distribution House of culture publishing, Amman, Jordan.

Alhelow Borhan Sabah. (2000). The impact of the use of information systems and technology of integrated banking services in Jordanian banks from the perspective of banking leaders, unpublished Master thesis, Al al-Bayt University, Jordan,

Anderson,D. R,Sweeney,D. J,, \& Williams,T. A. (1990). Statistics for Business and Economics. 4 th ed., West Publishing Company. 
Bodnar, Jeorge H., \& William S. Hopwood. (1995). Accounting Information System, Englewood Cliffs, N. J. Prentice-Hall.

Date,C. J.(2000). An Introduction to Database Systems, Seven Edition, Addison-Wesley publishing Company.

Emad Al-Hadithi, Saleh N'meh,(1993). Assesses internal control systems for organizations that use a computer, a field study on financial and banking institutions in the Hashemite Kingdom of Jordan, unpublished Master thesis, University of Jordan, Amman.

Gomaa Ahmed Helmy et al. (2003). Accounting information systems, contemporary application Portal Edition.

Jamoos ,Yasser. (1991). Review accounting systems that rely on computer use, unpublished Master thesis, University of Aleppo, Syria.

kokhon Dalal, Khalil. (1988). Accounting control under electronic systems and their applications in the Jordanian Central Bank, unpublished Master thesis, University of Jordan, Amman.

Murad ,Ali Khaled Alradedeh. (1998). The effect processors, the mechanism of accounting information systems, applied study in Jordanian customs service, unpublished Master thesis, $\mathrm{Al}$ al-Bayt University, Mafraq,

Ramadan, Abdel Hadi Hamid. (1999). factors affecting accounting information systems in Jordanian public shareholding industrial enterprises, unpublished Master thesis, University of Jordan, Amman.

Qassim ,Abdul Razak Mohamad. (2004). information systems analysis and design, first Edition, publishing house of culture. 